\title{
Non-surgical Root Canal Retreatment: A Retrospective Outcome Study
}

\author{
Cerrahi Olmayan Kök Kanal Tedavi Yenilemesi: Retrospektif \\ Başarı Değerlendirmesi
}

\author{
(D) Senem Yiğit Özer \\ Aydın Adnan Menderes University Faculty of Dentistry, Department of Endodontics, Aydın, Turkey
}

Keywords

Retreatment, root canal treatment, longterm, treatment outcome

\section{Anahtar Kelimeler}

Kanal tedavisi yenilenmesi, kök kanal tedavisi, tedavi başarısı, uzun dönem

Received/Geliş Tarihi : 21.04.2020

Accepted/Kabul Tarihi : 27.05.2020

doi:10.4274/meandros.galenos.2020.68736

Address for Correspondence/Yazışma Adresi: Senem Yiğit Özer MD,

Aydın Adnan Menderes University Faculty of Dentistry, Department of Endodontics, Aydın, Turkey

Phone : +90 5324760051

E-mail : senem@adu.edu.tr

ORCID ID: orcid.org/0000-0002-2360-3942

(C) Meandros Medical and Dental Journal, Published by Galenos Publishing House.

This is article distributed under the terms of the Creative Commons Attribution NonCommercial 4.0 International Licence (CC BY-NC 4.0).

\begin{abstract}
Objective: When the prognosis of a root canal treated (RCT) teeth is poor, retreatment (RT) of the former RCT is indicated. The aim of this study was to assess the long-term success rate of nonsurgical retreatment for five years.

Materials and Methods: RTs were performed on 132 patients in 2013-2014; after drop-outs, 83 patients were enrolled clinically and radiographically after 5 years. The parallel-cone technique was used with a film holder, and radiographs were saved in JPEG format for further evaluation. In addition, intra-oral examinations were performed for RTs at 6 months and 1 to 5 years.

Results: After 5 years of follow-up, only 83 of the 132 patients could be reached and assessed. Following RTs, $10.8 \%(n=9)$ of the patients were symptomatic on percussion, 6.2\% $(n=5)$ patients had sinus tracts with different diameters, $83 \%$ $(\mathrm{n}=69)$ of the patients were accepted as "healed teeth", and 17\% $(n=31)$ patients were accepted as "unhealed". When the quality of the root canal obturation after RT was evaluated, the number of root canal obturations short of the working length were evaluated. $84.3 \%$ of the root canals were accepted as "good" and 15.7\% of the others were accepted as "short" root canals.

Conclusion: Providing the proper working length may help to eliminate residual bacteria in the untouched regions and improve the quality of the new treatment for tooth survival in regard to better disinfection.
\end{abstract}

Öz

Amaç: Kök kanal tedavisi (KKT) başarısız olduğunda tedavinin yenilenmesi (TY) endikedir. Bu araştırmada, cerrahi olmayan TY'nin uzun dönemde gösterdiği başarı oranının değerlendirilmesi amaçlanmıştır.

Gereç ve Yöntemler: 2013-2014 yılları arasında TY'si tamamlanan 132 hasta, gerek klinik olarak gerekse radyolojik inceleme ile 5 sene boyunca takip edildi. Bu süre içerisinde, kayıplar ile birlikte 83 hastaya erişildi. Paralel-kon tekniği kullanılarak alınan radyografiler JPEG formatında saklandı ve değerlendirildi. Hastaların intraoral muayeneleri TY'den sonra 6 ay ve 1-5 sene arasında tamamlandı.

Bulgular: TY'sini takiben \%10,8 ( $n=9)$ hastada perküsyon sırasında duyarlılık kayıt edildi. \%6,2 ( $n=5)$ oranında, farklı çaplarda fistül varlığı saptandı. \%83 ( $n=69)$ oranında hasta "tamamen iyileşmiş" olarak kabul edildi. Bununla birlikte, \%17 $(n=31)$ oranında "iyileşmeyen" hasta olduğu saptandı. TY'den sonra, kök kanal dolgusunun kalitesi değerlendirildiğinde, çalışma uzunluğuna ulaşmayan kök kanallarının sayısı belirlendi. Kök kanallarının \%84,3'nün "uygun", \%15,7'sini "kısa" dolgular olduğu görüldü. 
Sonuç: Etkin dezenfeksiyonun sağlanması için, TY'lerinde çalışma uzunluğu boyunca şekillendirme yapabilmek gerekir. Bu şekilde, eğenin kök kanal duvarlarına temas etmeyen bölgelerinde dokunulmadan kalan bakterilerin yok edilmesi sağlanarak dişin sağkalımı için gerekli olan tedavi kalitesi artırılmış olur.

\section{Introduction}

Objectives of successful root canal treatment (RCT) are mainly the debridement of the root canal system, a wellmatched root canal preparation conserving the original form, disinfection and obturation of the root canal system hermetically (1). In case of unsuccessful treatment outcome; retreatment (RT) is the first choice in treatment planning (2). Data regarding success in the outcome of RT is between 40 to $99 \%$ (2). In cases where RTs are unsuccessful; apical surgery of the root, intentional replantation of the tooth or tooth extraction may be necessary (3). Main issue in RT is solely extracting out the remained gutta-percha and root canal sealer of the former RCT, reaching the original apical foramen of the root canal system, attaining full disinfection through the system and eliminating the residual bacterial contamination $(4,5)$.

European Society of Endodontology has declared the guidelines regarding types of healing after RCT in 2006. According to this guideline, healing after RCT has been classified under three groups (6):

Total healing; a. absence of pain, swelling, sinus tract and function b. normal lamina dura c. no sensitivity during percussion and palpation $\mathrm{d}$. healthy periodonsium.

Incomplete healing; a. intraorally asymtomatic $b$. no change in the volume of the periapical lesion or little healing trabecularly.

Disease; a. symptoms indicating infection $b$. increase in the volume of the periapical lesion or formation of a new lesion c. no change in the volume of the periapical lesion after 4 years following RCT $d$. root resorption.

Regarding of the aforomentioned issues; only RCTs in the "Total Healing" group are accepted as 'successful'. In addition, evaluating the RCTed tooth radiographically, there should be no signs of internal/ external root resortion, continuity in lamina dura, no voids/gaps through the obturation material and decrease in the volume of the periapical lesion are the determinants of healing radiographically.
Treatment outcome of RT may be affected due to gender, age, and systemic health of the patient. Different grouping of the teeth as like the molars or incisors, volume of the periapical lesion, homogenity of the former root canal obturation, iatrogenic problems regarding the former RCT as like ledgeding, separation of the files, presence of cracks or fractures, problems in isolation of the tooth, skills of the operator, having trouble to reach the working lenght and improper disinfection of the former RCT may act as untoward mechanicsms against proper healing (7).

Thus the aim of the present study was to make an assessment on the long-term success rate of nonsurgical RTs performed in Aydın Adnan Menderes University, Faculty of Dentistry, Department of Endodontics.

\section{Materials and Methods}

\section{Ethical approval}

This retrospective study was approved by the Committee for Research on Non-Human Subjects at the Aydın Adnan Menderes University Faculty of Medicine, Aydın, Turkey (Dnr: ADUTIPGOEK protocol no: 2015/731)

\section{Patients and Teeth}

The subjects were 132 patients referred to the department of endodontics for RT due posttreatment disease.

Patients fulfilling the following inclusion criteria were consecutively enrolled:

a. All single and multiple rooted maxillary and mandibular teeth, which apical radiolucency was clearly visible on X-rays,

b. RCT performed more than 2 years earlier or the presence of clinical signs and symptoms,

c. Periodontally healthy gums without deeep local pocket penetration,

d. Age over 18,

e. Patient consent was obtained,

Exclusion criteria were as follows:

a. Presence of any kind of posts through the root cana, 
b. Presence of fractured root canal instruments

c. Teeth with a mobility over grade 2 ,

d. Patients with chronic diseases as like diabetes mellitus,

e. Internally or externally resorbed tooth,

f. Patients unwilling to join the follow-ups.

RT procedures were completed under the same protocols with two experienced endodontists (S.Y.Ö and H.D.Ö). Using 2\% Lidocaine, 1:80,000 epinephrine (Jetokain, Adeka, İstanbul, Turkey) was injected with rubber-dam isolation. Former root canal obturation material was removed mechanically using ProTaper RT files (Dentsply Maillefer, Ballaigues, Switzerland) coded D1 to D3. After reaching the original apical foramen using hand files from \#6-15; working length was determined. Preparation was completed using ProTaper Next files from X1 to X3 (and X4; where necessary) and $2 \mathrm{~mL}$ of $2.5 \%$ sodium hypochlorite (NaOCl) (Atayan Kimya, İzmir, Turkey) was used between each file. Final irrigation was performed using 2.5\% NaOCl, 17\% EDTA (Sigma Chemical Co, St Louis,USA) and 2\% chlorhexidine gluconate (Klorhex, Drogsan, Turkey) with a 30-gauged endodontic irrigation needle (Mekan Med., Shanghai, China). An interappointment dressing of calcium hydroxide paste was placed with a Lentulo spiral and access cavities were temporarily dressed using glass ionomer cement (GC Fuji, Minnesota, USA) After 1 week, the root canals were reentered and filled with gutta-percha using cold-lateral compaction technique with a resin based root canal sealer (AD Seal, Meta BioMed, South Korea). Root canal orifices were sealed using a flowable resin composite (Filtek ${ }^{\mathrm{TM}}$ Bulk Fill Flowable Restorative, 3M ESPE, St. Paul, MN, USA) and than teeth were restored using a posterior resin composite (G-ænial posterior, GC Corp, Japan).

\section{Follow-up}

RTs were performed on 132 patients between 2013-2014, and just after drop-outs, 83 patients were enrolled clinically and radiographically after 5 years. A parallel-cone technique was used with a film holder (Kerr Dental, California, USA), in order to standardize the angulation of the radiographs. Radiographs were saved in JPEG format for further evaluation.

Regarding the intra-oral examination during followup period; the evaluation criteria were: a. presence/absence of sinus tract,

b. presence/absence of sensitivity during palpation and percussion,

c. presence/absence of spontaneous pain or pain on chewing.

Patients were recalled after 6 months and 1 to 5 years after the RTs for each year. During this period, there were totally 49 drop-outs due to reluctance for follow-up, moving to other cities and tooth extraction.

During radiographic evaluation, for changes in surrounding bone and periapical portion; a 5-step scoring system was used on the base of periapical index (PAI) (8). PAl uses standardized radiographic images including the healing stages of bone; in five different phases. The system provides an ordinal scale of 5 scores ranging from 1 (healthy) to 5 (severe periodontitis with exacerbating features). Its validity is based on the use of reference radiographs of teeth with verified histological diagnoses. Pre and post operative radiographs were evaluated and scored using the PAl; and healing/non-healing were assessed according to those scores.

Teeth scored on PAI 1 and PAI 2 (PAI $\leq 2$ ) were accepted successful as "healed"; on contrary, teeth scored on PAI 3, PAI 4 and PAI 5 (PAI $\geq 3$ ) were accepted unsuccessful as 'unhealed' RTs.

\section{Statistical Analysis}

Statistical analysis was performed using SPSS 15.0 software (SPSS Inc, Chicago, IL). Data were analyzed descriptively, using means and standard deviations. Inter-observer and intra-observer agreement scores were evaluated usuing Weighted Kappa. Healing scores regarding time were evaluated using Holm-Sidak Multiple Comparative test. All hypothesis tests were two-tailed and conducted at the 0.05 level of significance.

\section{Results}

After 5 years of follow-up, only 83 of 132 patients were reached and assessed. There were 49 dropouts. After 5 years, following RTs; $10.8 \%(n=9)$ of the patients were symptomatic on percussion. $6.2 \%(n=5)$ patients had sinus tracts with different diameters. On the other hand; $83 \%(n=69)$ of the patients were accepted as 'healed teeth'. However, $17 \%(n=31)$ patients were accepted as 'unhealed' ratio (Tables 1, 2). 
When the quality of the root canal obturation after RT was evaluated, number of root canal obturations which are short of the working length were evaluated. $84.3 \%$ of the root canals were accepted as "good" and $15.7 \%$ of the others were accepted as "short" root canals (Table 3).

After 5 years of follow-up; with 49 drop-outs; 83 patients' teeth were healed cases. Sinus tracts were also recorded and evaluated as non-healed cases. Comparative analysis indicated that; when working length was acceptable; those cases healed without problems. There was direct relationship between the evaluated parameters.

The intraclass coefficient varied from 0.87 to 0.94 for Observer 1, 0.85 to 0.93 for Observer 2, resulting statistically no difference between the observers ( $p>0.05)$.

\section{Discussion}

There are studies examining the success of RCT on a community basis, as well as studies evaluating the factors affecting this success (9). The results differs vastly from each other as like; depending on the
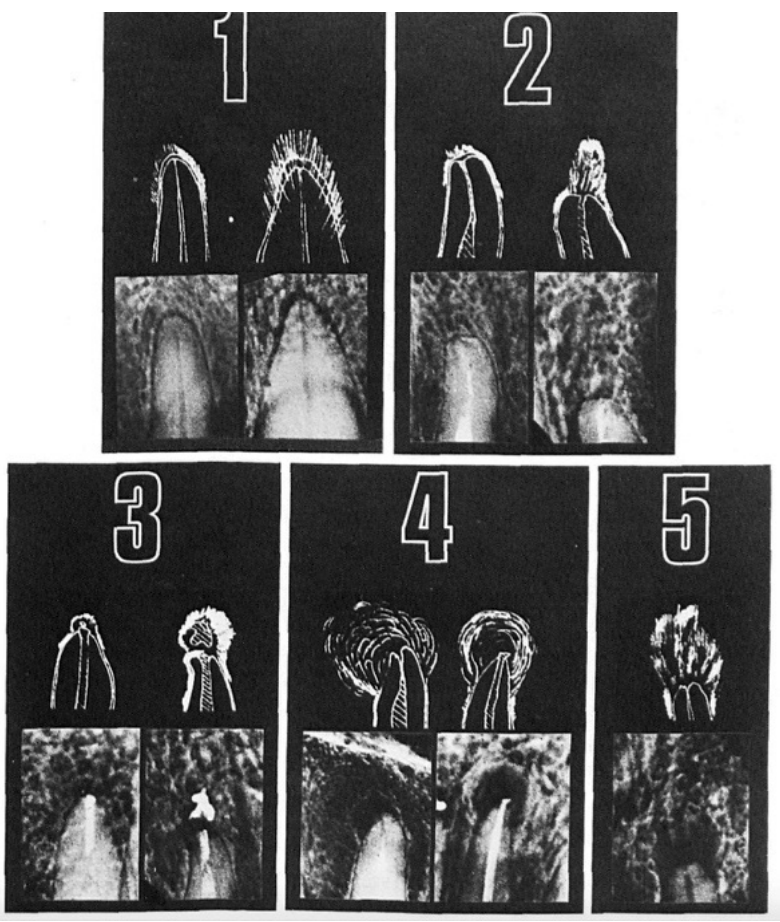

Figure 1. PAI Scores 1 to 5 are related with matching radiographic status

PAI: Periapical index

Table 1. Periapical index scoring system (8)

\begin{tabular}{|l|l|}
\hline PAl scores & Appereance on radiograph \\
\hline 1 & Periapical destruction of bone almost definitely not present \\
\hline 2 & Periapical destruction of bone probably not present \\
\hline 3 & Unsure \\
\hline 4 & Periapical destruction of bone probably present \\
\hline 5 & Periapical destruction of bone almost definitely present \\
\hline PAI: Periapical index & \\
\hline
\end{tabular}

Table 2. Healed and unhealed teeth ratio after 5 years following retreatment

\begin{tabular}{|l|l|l|l|}
\hline Intra-oral findings & $(\mathbf{n})$ & $\mathbf{( \% )}$ & Standart deviation mean difference \\
\hline Symptomatic & 9 & 10.8 & 0.28 \\
\hline Asymptomatic & 69 & 83 & 0.23 \\
\hline Sinus Track & 5 & 6.2 & 0.19 \\
\hline Total & 83 & 100 & \\
\hline
\end{tabular}

Table 3. Working length assessment after retreatments

\begin{tabular}{|l|l|l|l|}
\hline Working lenght of RT & $(\mathbf{n})$ & $\mathbf{( \% )}$ & Standart deviation Mean Difference \\
\hline Acceptable & 70 & 84.3 & 0.14 \\
\hline Short of working length & 13 & 15.7 & 0.21 \\
\hline RT: Retreatment & & \\
\hline
\end{tabular}


study design, types of teeth, different equipment and treatment methods on cases, the experience of the operator performing the treatment, the total number of the evaluated patients and drop-outs, the imaging techniques used, the duration of the monitoring and statistical analysis (10-15).

While success for the patient may be defined as an adequately RCT without any signs and symptoms and tooth in function for chewing (15); the clinician evaluates the success of the RCT as a healed or nonhealed lesion in the periapical region with the filling of the radiographically satisfactory image without any clinical signs of pain $(12,13)$.

In retrospective studies evaluating the success of RCT, there are studies in which RT and primary endodontic treatments are compared to each other $(9,13,14)$, however there are also studies which especially do not corroborate RT cases. Since we thought that the presence of symptoms, the quality of primary endodontic treatment and the presence of periapical lesion may not affect total treatment outcome, long-term effects of orthograde RT on clinical success rate was evaluated in our study.

Regarding clinician's experience on treatment outcome, it is very difficult to achieve a certain standardization in retrospective studies. In some of the studies, undergraduate students $(10,11,13,15)$ were labeled as post-doctoral students (16) and the operators'experience was ignored (17-19). In order to eliminate these drawbacks; in our study patients were solely retreated by two experienced endodontists.

In addition, it is debated whether the selected patient group reflects the general society or not, and the selection of university hospitals with a larger spectrum of patient potential and diversity may be more accurate in terms of validity of the results (20).

The recall rate of patients, evaluating the success of previously completed RCT teeth is generally similar. For different reasons, patients were recalled simply by contacting both written invitations and telephone. In these studies, response rates of $18 \%(21), 20 \%(10)$, $38 \%(14)$ and $51 \%$ recall rate of $4-6$ years of followup period was given, which may be considered to be higher than the evidence level. This rate can be attributed to the fact that the studies were conducted in smaller communities and that there were less patients in comparision groups. In our study, nearly $65 \%$ of the treated patients replied the recalls in five years and when comparing this recall rate; our study may be accepted as a successful appraisal research.

When making a decision on a correlation between root canal filling's ending levels and treatment outcome; Strindberg (22) stated that when the root canal filling level ends $1 \mathrm{~mm}$ shorter than the radiological apex, the highest success is achieved. Similarly Ricucci et al. (23) found that the higher the coronal termination of the canal filling from the radiological apex in the vital teeth is $1.5 \mathrm{~mm}$; in like manner, this distance would be ideal as $2 \mathrm{~mm}$ in devital teeth.

Using electronic apexlocaters would be helpful to the clinician as well as using other imaging technologies in RT cases. In our study; after removal of former gutta-percha and root canal sealer; coronal and middle thirds of the root canals were prepared using a tapered rotary file in order to remove all former obturation material for more electronic accurate reading (24). Data indicate that, the acceptable working length was achieved in $84 \%$ of the patients; which brings success in RT outcome in its wake, with a rate of $83 \%$ (rate of asymptomatic patients after 5 years).

\section{Conclusion}

There are many considerations on successful treatment outcome for retreated teeth. Providing the proper working length may help to eliminate residual bacterias of the untouched regions and improve the new treatment quality for tooth survival in regards of better disinfection.

\section{Ethics}

Ethics Committee Approval: This retrospective study was approved by the Committee for Research on Non-Human Subjects at the Aydın Adnan Menderes University Faculty of Medicine, Aydın, Turkey (protocol no: 2015/731).

Informed Consent: An informed consent was obtained from all patients.

Peer-review: Externally peer-reviewed.

Financial Disclosure: The author declared that this study received no financial support.

\section{References}

1. Schilder H. Cleaning and shaping the root canal. Dent Clin North Am 1974; 18: 269-96. 
2. Paik S, Sechrist C, Torabinejad M. Levels of evidence for the outcome of endodontic retreatment. J Endod 2004; 30: 745-50.

3. Stabholz A, Friedman S. Endodontic retreatment - case selection and technique. Part 2: Treatment planning for retreatment. J. Endod 1988; 14: 607-14.

4. Imura N, Kato AS, Hata GI, Uemura M, Toda T, Weine F. A comparison of the relative efficacies of four hand and rotary instrumentation techniques during endodontic retreatment. Int Endod J 2000; 33: 361-6.

5. Schirrmeister JF, Wrbas KT, Schneider FH, Altenburger MJ, Hellwig E. Effectiveness of a hand file and three nickel-titanium rotary instruments for removing gutta-percha in curved root canals during retreatment. Oral Surg Oral Med Oral Pathol Oral Radiol Endod 2006; 101: 542-7.

6. European Society of Endodontology. Quality guidelines for endodontic treatment: consensus report of the European Society of Endodontology. Int Endod J 2006; 39: 921-30.

7. Çalışkan MK. Endodontide Tanı ve Tedaviler. Nobel Tıp Kitabevi, İstanbul 2006: 136-7.

8. Orstavik D. Time-course and risk analyses of the development and healing of chronic apical periodontitis in man. Int Endod J 1996; 29: 150-5.

9. Ng YL, Mann V, Gulabivala K. A prospective study of the factors affecting outcomes of nonsurgical root canal treatment: Part 1: periapical health. Int Endod J 2011; 44: 583-609.

10. Trope M, Delano EO, Orstavik D. Endodontic treatment of teeth with apical periodontitis: Single vs. multivisit treatment. J Endod 1999; 25: 345-50.

11. Dorasani G, Madhusudhana K, Chinni SK. Clinical and radiographic evaluation of single visit and multi-visit endodontic treatment of teeth with periapical pathology: An in vivo study. J Conserv Dent 2013; 16: 484-8.

12. Ray HA, Trope M. Periapical status of endodontically treated teeth in relation to the technical quality of the root filling and the coronal restoration. Int Endod J 1995; 28: 12-8.

13. Eliyas S, Briggs PFA, Harris IR, Newton JT, Gallagher JE. Development of quality measurement instruments for root canal treatment. Int Endod J 2017; 50: 652-66.

14. Huumonen S, Ørstavik D. Radiographic follow-up of periapical status after endodontic treatment of teeth with and without apical periodontitis. Clin Oral Investig 2013; 17: 2099-104.

15. Stoll R, Betke $K$, Stachniss V. The influence of different factors on the survival of root canal fillings: a 10-year retrospective study. J Endod 2005; 31: 783-90.

16. Fonzar F, Fonzar A, Buttolo P, Worthington HV, Esposito M. The prognosis of root canal therapy: a 10-year retrospective cohort study on 411 patients with 1175 endodontically treated teeth. Eur J Oral Implantol 2009; 2: 201-8.

17. Nair PN, Sjögren U, Krey G, Sundqvist G. Therapy-resistant foreign body giant cell granuloma at the periapex of a root-filled human tooth. J Endod 1990; 16: 589-95.

18. Touboul V, Germa A, Lasfargues JJ, Bonte E. outcome of endodontic treatments made by postgraduate students in dental clinic of bretonneau hospital. Int J Dent 2014; 30: 1-11.

19. Hoskinson SE, Ng YL, Hoskinson AE, Moles DR, Gulabivala K. A retrospective comparison of outcome of root canal treatment using two different protocols. Oral Surg Oral Med Oral Pathol Oral Radiol Endod 2002; 93: 705-15.

20. Castelot-Enkel B, Nguyen JM, Armengol V, Volteau C, Laboux O, Lombrail $P$. A recall program for the outcome of conventional root canal treatment performed in a teaching hospital. Acta Odontol Scand 2013; 71: 1399-409.

21. Dammaschke T, Steven D, Kaup M, Ott KH. Long-term survival of root- canal-treated teeth: a retrospective study over 10 years. J Endod 2003; 29: 638-43.

22. Strindberg LZ. The dependence of the results of pulp therapy on certain factors: an analytic study based on radiographic and clinical follow-up examinations, Mauritzon. 1956.

23. Ricucci $D$, Russo J, Rutberg $M$, Burleson JA, Spångberg LS. $A$ prospective cohort study of endodontic treatments of 1,369 root canals: results after 5 years. Oral Surg Oral Med Oral Pathol Oral Radiol Endod 2011; 112: 825-42.

24. Mancini M, Palopoli P, Iorio L, Conte G, Cianconi L. Accuracy of an electronic apex locator in the retreatment of teeth obturated with plastic or cross-linked gutta-percha carrier-based materials: an ex vivo study. J Endod 2014; 40: 2061-5. 